\title{
CHARACTERIZATION AND CIPROFLOXACIN ADSORPTION PROPERTIES OF ACTIVATED CARBONS PREPARED FROM VARIOUS AGRICULTURAL WASTES BY KOH ACTIVATION
}

\author{
TO-UYEN T. DAO, ${ }^{* * * *}$ HONG-THAM T. NGUYEN,,$* * * * *$ \\ DUYEN THI CAM NGUYEN, ${ }^{* * * * *}$ HANH T.N. LE, ${ }^{* * * *}$ HUONG T.T. NGUYEN, ${ }^{*}$ SY TRUNG DO, ${ }^{* * * * *}$ HO \\ HUU LOC, ${ }^{* * *}$ TRUNG THANH NGUYEN, ${ }^{* * * * * *, * * * * * * * *}$ TRINH DUY NGUYEN ${ }^{* * * * * *}$ \\ and LONG GIANG BACH ${ }^{*, * * * *}$ \\ "Center of Excellence for Green Energy and Environmental Nanomaterials (CE@GrEEN), \\ Nguyen Tat Thanh University, 300A Nguyen Tat Thanh, District 4, Ho Chi Minh City, Vietnam \\ ** Department of Chemical Engineering, HCMC University of Technology, \\ VNU-HCM, Ho Chi Minh City, Vietnam \\ ${ }^{* * * *}$ NTT Hi-Tech Institute, Nguyen Tat Thanh University, 300A Nguyen Tat Thanh, \\ District 4, Ho Chi Minh City, Vietnam \\ ${ }^{* * * *}$ Institute of Hygiene and Public Health, 159 Hung Phu, Ward 8, District 8, \\ Ho Chi Minh City, 700000, VietNam \\ ${ }^{* * * * *}$ Institute of Chemistry, Vietnam Academy of Science and Technology, 18 Hoang Quoc Viet Str., \\ Cau Giay District, Hanoi City, Vietnam \\ ${ }^{* * * * * * *}$ Faculty of Engineering, Technology, Environment, An Giang University, Vietnam \\ ${ }^{* * * * * * *}$ Vietnam National University Ho Chi Minh City, Ho Chi Minh City, Vietnam \\ Corresponding authors: T.-U. T. Dao, touyen2407@gmail.com \\ L. G. Bach, blgiang@ntt.edu.vn
}

Received January 17, 2020

Agricultural waste is a renewable and readily available resource that is used as a precursor to synthesize coal to reduce production costs. Significantly, valorizing it would greatly improve the quality of living in rural and remote areas. In this study, agricultural waste from straw, Limonia acidissima shell, avocado shell, tea waste and banana peel were used as precursors to prepare activated carbon. The desired surface area and pore size of carbonized materials was achieved by the chemical activation method, using $\mathrm{KOH}$ as an activating agent at a temperature of $500{ }^{\circ} \mathrm{C}$. Scanning electron microscopy (SEM) and X-ray diffraction were used to determine surface morphology and amorphous carbon formation. The surface functional groups of carbonized materials were characterized by Fourier transform infrared spectroscopy (FT-IR) and $\mathrm{N}_{2}$ adsorption-desorption isotherms, which revealed the specific surface area (BET) of the five activated carbon materials. The analytical results show that the activated carbon produced from straw exhibits superior characteristics and the highest ciprofloxacin removal efficiency among the five types of activated carbon. The surface area reached $494.92 \mathrm{~cm}^{2} / \mathrm{g}$ and total pore volume reached $0.494 \mathrm{~cm}^{3} / \mathrm{g}$. Moreover, the ciprofloxacin adsorption efficiency reached $93.34 \%$ at a concentration of $20 \mathrm{mg} / \mathrm{L}$. The results of this study indicate that activated carbon made from industrial waste has the potential to be used for removing antibiotics from aqueous environment.

Keywords: agricultural waste, ciprofloxacin, activated carbon, adsorption

\section{INTRODUCTION}

For decades, new adsorbent generations have received much attention from many researchers due to the important benefits that they brought. ${ }^{1-3}$ Regarding environmental issues, the major role of these adsorbents relies in the fact that they become capable of completely adsorbing a large amount of toxic pollutants, such as heavy metals, ${ }^{4}$ organic dyes, ${ }^{5}$ toxic solvents ${ }^{6}$ and antibiotics ${ }^{5}$ from aqueous media. When it comes to these adsorbents, the most prominent one is activated carbon due to its advantages, such as high porosity, high specific surface area, suitable pore 
size and the presence of functional groups on the surface of the material, which can contribute significantly to the adsorption process. ${ }^{9-11}$ The precursors, which are utilized as input materials for carbonization to create activated carbons, should be inexpensive in order to minimize the production cost of the final products and to widen their applications towards other potential fields, such as catalysis, drug delivery and electrocatalysis. Agricultural waste is a renewable and readily available resource that has been already used as a precursor to synthesize some products, such as biochar, biofuel and fertilizer. Therefore, expanded utilization of this resource in adsorbent manufacturing could reduce manufacture costs and significantly improve the quality of living in rural and remote areas. ${ }^{12}$

A wide range of studies are known to report on the use of activated carbons (AC) from agricultural waste in the adsorption field. For example, Inyang et al. published a short review on biochar-derived low-cost adsorbents and their applications in heavy metal removal from wastewater. ${ }^{13}$ Norouzi et al. reported on the synthesis of activated carbon produced from date press cake (DPC) by using $\mathrm{NaOH}$ solution under various activation conditions. Thanks to the high specific surface area $\left(2025.9 \mathrm{~m}^{2} / \mathrm{g}\right)$ and microporous texture $(86.01 \%)$, the as-synthesized activated carbon achieved very high adsorption capacities of $\mathrm{Cr}(\mathrm{VI})$ from aqueous solution, with maximum adsorption capacities reaching 282.8 $\mathrm{mg} \mathrm{g}^{-1}(\mathrm{pH}=2)$ and $198.0 \mathrm{mg} \mathrm{g}^{-1}(\mathrm{pH}=5) .{ }^{14} \mathrm{In}$ the same trend, M. Brito et al. successfully synthesized AC from yellow mombin fruit stones to remove Dianix ${ }^{\circledR}$ royal blue $\mathrm{CC}$ dye, showing a maximum monolayer adsorption capacity of $147.47 \mathrm{mg} . \mathrm{g}^{-1}$ and $82.28 \mathrm{mg} . \mathrm{g}^{-1}$ for the acidic and basic treatments of activated carbons, respectively. ${ }^{15}$ George Z. Kyzas et al. fabricated zero cost activated carbon through a pyrolysis pathway using potato peels (ACP) as a carbonaceous source in the model of lead (II) elimination $(171 \mathrm{mg} / \mathrm{g})$. Norsafiah Fazli et al. reported kinetics and equilibrium in-depth studies on textile dyes using coconut shell derived activated carbon via adsorption models and investigated a series of physiochemical factors (e.g. contact time, concentration, adsorbent dosage, particle size, $\mathrm{pH}$ ) on the removal and adsorption efficiency. ${ }^{16}$ More intensively, a series of other biomass-based materials, which can be derived from many biomass resources, e.g. sugarcane bagasse, rice straw, tea waste and graphene oxide, have been used to remove heavy metals in these studies. ${ }^{17-19}$ Therefore, activated carbon has been considered as an efficient adsorbent to remove pollutants from aqueous media. ${ }^{20-26}$

Antibiotics are one of the most important groups of pharmaceutical compounds used to prevent and treat diseases. ${ }^{27}$ Most antibiotics are not totally metabolized in the body of humans and animals, and could be released in the form of feces and urine wastes, leading to their appearance within aqueous media in hospital municipal wastes. On the other hand, excessive use of antibiotics for shrimp and fish farming can aggravate the issue, as wastewater discharged from farming activities into the environment usually remains untreated. Therefore, the removal of antibiotics is a topic that has attracted considerable attention in recent studies. For example, Mithun Sarker et al. reported on the huge potential for using carbon nanomaterials obtained from metal-organic framework melamine-loaded MAF-6 (CDM@M-6) to remove nitroimidazole antibiotics (NIABs) including dimetridazole $(621 \mathrm{mg} / \mathrm{g})$ and metronidazole $(702 \mathrm{mg} / \mathrm{g})$ - from wastewater. ${ }^{28}$ With very high adsorption capacities, CDM@M-6 is regarded as a nanomaterial capable of dealing with NIABs pollutants. Pharmaceuticals and personal care products are found as emergent polluting sources when their demand has been increasing. Biswa Nath Bhadra et al. indicated the vital role of bio-MOF-1 derived porous carbon in selectively treating compounds, such as atenolol $(552 \mathrm{mg} / \mathrm{g})$ and acidic clofibric acid $(540 \mathrm{mg} / \mathrm{g}){ }^{29}$ In particular, the materials synthesized could be easily recycled and were chemically stable, providing a promising case study to convert a labscale product to practical application.

Among typical antibiotics, ciprofloxacin (CIP) is a widely prescribed antibiotic for the treatment of bacterial and respiratory infections. ${ }^{30}$ The occurrence of CIP antibiotic in the environment has been found in higher concentrations than other antibiotics. ${ }^{7,31}$ More seriously, their existence, even in low concentrations, can lead to the development of antibiotic resistance in bacteria. ${ }^{32}$ This impairs the potency of antibiotics that are normally effective in disease treatment or renders them useless. Therefore, the removal of antibiotics from the water environment by effective methods and the development of adsorbent materials from available and cheap raw materials are essential. In previous studies, the use 
of nanomaterials has been widely reported for this purpose. El-Shafey et al. used date palm leaflets as an outstanding carbonaceous source to achieve a highly porous structure via anhydrous $\mathrm{H}_{2} \mathrm{SO}_{4}$ carbonization at $160{ }^{\circ} \mathrm{C}^{33}$ Since the proposed adsorption mechanisms via ion exchange and $\mathrm{H}$ bonding significantly contribute to fast CIP removal, it is concluded that this kind of carbon can be a prospective alternative adsorbent. Via an important chemical modification, amino groups $\left(\mathrm{NH}_{2}-\right)$ attachment on MIL-53(Fe) based nanomaterials has been proved to enhance their porosity, to achieve higher surface area and pore volume $\left(215.1 \mathrm{~m}^{2} / \mathrm{g}\right.$ and $0.2 \mathrm{~cm}^{3} / \mathrm{g}$, respectively), as well as better maximum adsorption capacity, of $102.5 \mathrm{mg} / \mathrm{g} .{ }^{34}$ However, the use of high cost materials may be unfavorable to CIP adsorption, therefore, lower cost biomass derived materials are sought to be developed.

In this study, agricultural wastes, such as straw, Limonia acidissima shell, banana peels, tea waste and avocado shells, were used as precursors to remove CIP from the aquatic environment. All the carbon materials were activated with $\mathrm{KOH}$ and calcined at a temperature of $500{ }^{\circ} \mathrm{C}$. The properties of the materials were characterized using XRD (X-ray diffraction method), SEM (scanning electron microscopy), FTIR (Fourier transform infrared spectroscopy) and BET surface area analysis. Adsorption experiments were also carried out to assess the adsorption capacity of the prepared activated carbon. The adsorbents made from biological materials can enhance cost effectiveness and are environmentally friendly.

\section{EXPERIMENTAL}

Preparation of activated carbon from agricultural waste

Five types of agricultural waste, such as straw, banana peel, avocado peel, tea waste and Limonia acidissima shell, were used to synthesize five kinds activated carbon. The precursors were dried in the sun for 2-3 days and crushed into powder. Then, $20 \mathrm{~g}$ of dry powder was activated with $\mathrm{KOH}$ in a ratio of 1:1 $(\mathrm{g} / \mathrm{g})$ for 24 hours. The impregnated samples were dried for 24 hours at $105{ }^{\circ} \mathrm{C}$ to prepare the physical carbonization stage, with $99.9 \% \mathrm{~N}_{2}$ gas flow, at 500 ${ }^{\circ} \mathrm{C}$, when layers peel off, leading to a volume expansion of the material. This is the formation process of activated carbon. After that, the activated carbon was washed with distilled water and $2 \% \mathrm{HCl}$ solution several times until $\mathrm{pH}=7$, and then dried in an oven for 24 hours. The resulting activated carbon was stored in a desiccator for further analysis and characterization.
(\%) yield $=\frac{\text { weight of activated carbon }}{\text { weight of raw material }} * 100$

\section{Characterization of activated carbon}

The crystal structure of the material was confirmed by X-ray diffraction (XRD) on a D8 Advance Bruker system, using $\mathrm{Cu} \mathrm{K} \alpha$ stimulation with a scanning rate of $0.030^{\circ} / \mathrm{s}$ in the $2 \theta$ region of $5-80^{\circ}$. The crystal morphology of the material was observed by scanning electron microscopy (Scanning Electron Microscope, SEM, JSM 7401F, Jeol). The surface area and pore volume of the activated carbons were determined by the Brunauer-Emmett-Teller (BET) method, using a surface area analyzer (Gemini VII 2390, Micromeritics). The FT-IR spectra of the prepared activated carbons were recorded using a Fourier transform infrared spectrometer (Perkin-Elmer Spectrum One). The light absorption properties of the materials were analyzed via visible ultraviolet diffuse reflectance (UV-Visible Diffuse Reflectance Spectroscopy, UV-Vis-DRS, Shimadzu UV-2450) in the $300-900 \mathrm{~nm}$ wavelength range.

\section{Batch adsorption studies}

The adsorption efficiency of the materials was assessed based on the efficiency removal of CIP antibiotic. $^{35}$ The CIP adsorption capacity of AC was evaluated by the following procedure: $1 \mathrm{~g} / \mathrm{L}$ of adsorbent (AC) and $100 \mathrm{~mL}$ of CIP solution $(20 \mathrm{mg} / \mathrm{L})$ were added into a $250 \mathrm{~mL}$ glass beaker. The solution was stirred by a shaker, at a speed of $200 \mathrm{rpm}$ for a specified time period, and then centrifuged (7000 rpm) to separate the material from the antibiotic solution. Finally, the concentration of the remaining antibiotic was determined by spectrophotometry at the wavelength of $497 \mathrm{~nm}$. The removal efficiency was calculated based on the concentration before and after the adsorption process, according to the following equation:

Removal efficiency $(\%)=\left(1-\frac{\mathrm{C}}{\mathrm{C}_{\mathrm{o}}}\right) * 100$

where $\mathrm{C}_{\mathrm{o}}$ and $\mathrm{C}_{\mathrm{e}}$ are the initial and equilibrium antibiotic concentrations $(\mathrm{mg} / \mathrm{L})$, respectively.

\section{RESULTS AND DISCUSSION}

\section{Abbreviations of activated carbons}

The chemically activated carbon samples obtained from agricultural wastes, including straw (ST), Limonia acidissima shell (LAS), avocado shell (AS), tea waste (TW) and banana peel (BP), were named AC-ST, AC-LAS, AC-AS, AC-TW and AC-BP, respectively.

The straw was collected from Long An Province, Vietnam, which is located in the Mekong Delta. The humidity and ash contents of the straw were $11.2 \%$ and $2.25 \%$, respectively. 
The straw was cut to pieces with the length of 2-3 $\mathrm{cm}$ before being used.

\section{Characterization of activated carbons}

The crystal structure of the samples was determined by the X-ray diffraction method, as shown in Figure 1. A strong diffraction peak at $2 \theta$ $=\left(23.8^{\circ}-24.8^{\circ}\right)$, and a weak diffraction peak at $2 \theta$ $=\left(42.6^{\circ}-43.7^{\circ}\right)$ were observed in all the samples. These peaks confirm the presence of amorphous carbon in the currently studied samples. ${ }^{36-38}$

To identify functional groups on the surface of activated carbon, infrared spectra (FT-IR) of the as-synthesized AC materials were taken. Figure 1 (B) presents the infrared spectrum of activated carbon obtained by $\mathrm{KOH}$ activation, at a calcination temperature of $500{ }^{\circ} \mathrm{C}$. A broad spectrum band is found in the areas of surface functional groups, such as phenols, carboxylic acids and carboxylic acid derivatives, as well as the presence of physical adsorbed water on the material surface within $3554-2947 \mathrm{~cm}^{-1}{ }^{39}$ These bands are formed due to the stretching vibrations of the $\mathrm{O}-\mathrm{H}$ functional group and become wider in the case of oxidized coal. ${ }^{40}$ The valence oscillations of $\mathrm{C}-\mathrm{H}$ bonds of $-\mathrm{CH}_{2},-\mathrm{CH}_{3}$ groups were related to the peaks at $2898 \mathrm{~cm}^{-1}$ and 2810 $\mathrm{cm}^{-1}$. In addition, the characteristic position for C$\mathrm{O}$ and $\mathrm{C}=\mathrm{O}$ oscillations of ester, ketone, aldehyde, lactone or carboxylic acid groups appears in the area of 1486-1728 cm cm. $^{-11,42}$ The average adsorption of the carbonyl ester group $\mathrm{C}=\mathrm{O}$ of the lactone and phenol groups was observed in the range of $919-1438 \mathrm{~cm}^{-1} .{ }^{43}$ These functional groups greatly contribute to improved adsorption
Besides, to assess the morphological structure of the materials obtained, SEM images of the activated carbon samples were taken (Fig. 2). The results show that five samples of the obtained materials have rough external surfaces and are relatively porous, with different pore shapes and sizes, varying from a few tens to several hundred nanometers. In addition, the cell walls of parenchyma can be observed as common structures in plant parts, such as peel and petioles. ${ }^{43}$ Porosity can be observed on activated carbon surfaces, showing the effectiveness of activation and carbonization. However, a physical morphological characterization, such as " $\mathrm{N}_{2}$ adsorption-desorption", is necessary to determine these properties.

Nitrogen adsorption is an effective method to determine the properties of activated carbon, including porosity, surface area, pore volume and pore size. Figure 3 illustrates the nitrogen adsorption/desorption curves of the five activated carbons. The presence of mesopore-size pores in the five structures is evidenced by the hysteresis loops occurring on the adsorption curve at a relative pressure above 0.3 .

This indicates mesoporous adsorption of the activated carbon samples and signifies the formation and increase of mesoporosity as the temperature increases. ${ }^{36}$ The activation by $\mathrm{KOH}$ at high temperatures leads to widening the distance between the carbon atomic layers and an increase in the pore volume due to the burning of micropores into mesopores. Table 1 summarizes the results of the isotherms in terms of surface area, total pore volume and micropore volume. efficiency.
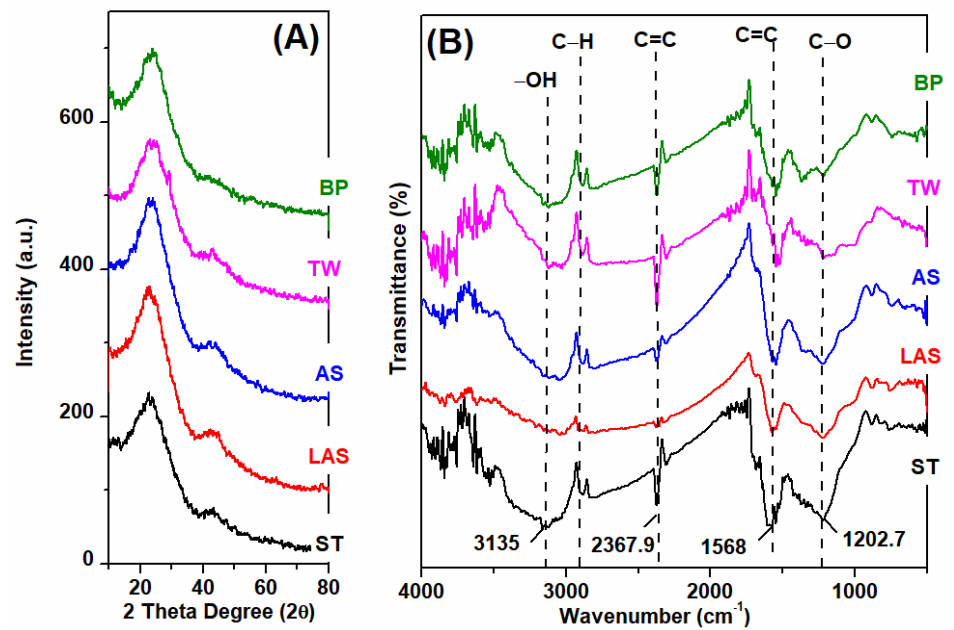

Figure 1: (A) X-ray diffraction patterns and (B) FT-IR spectra of prepared AC samples 

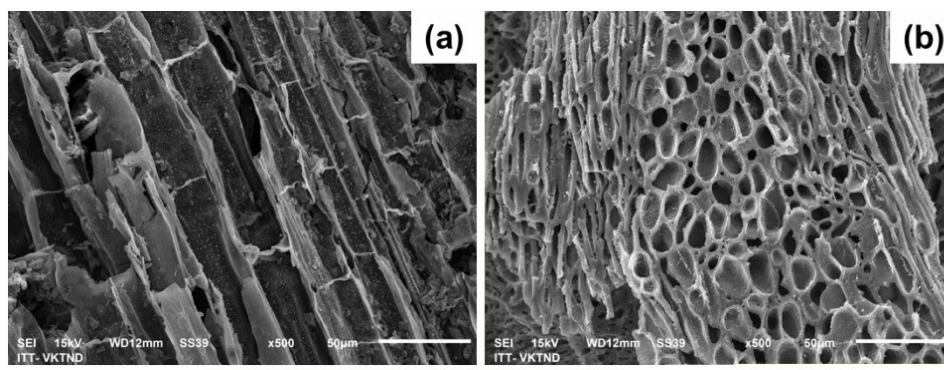

(b)
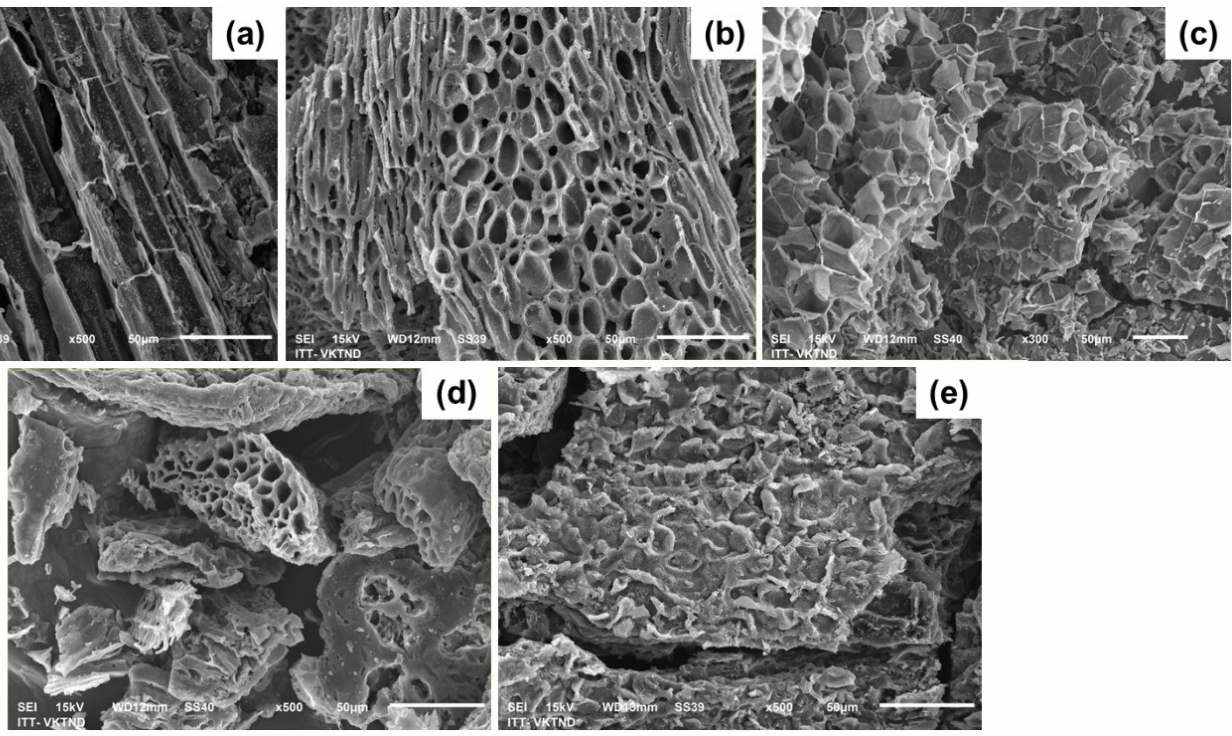

Figure 2: SEM micrographs of (a) AC-ST, (b) AC-LAS, (c) AC-AS, (d) AC-TW, and (e) AC-BP

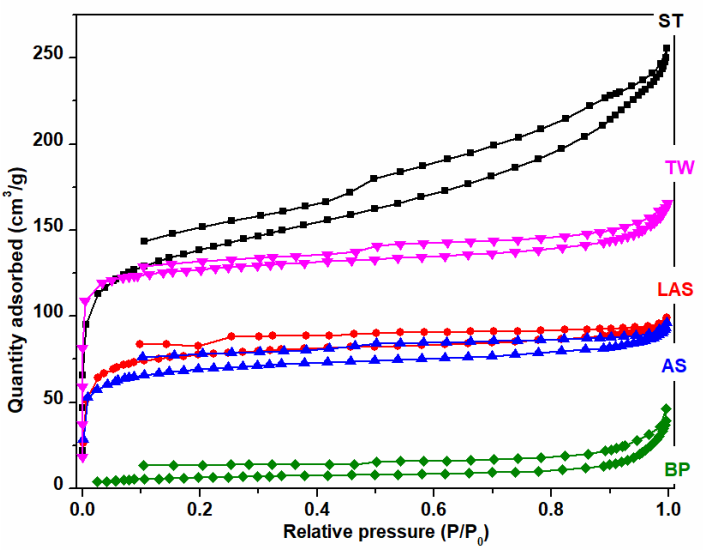

Figure 3: Nitrogen adsorption-desorption isotherms of activated carbon samples: (a) AC-ST, (b) AC-TW, (c) AC-LAS, (d) AC-AS, and (e) AC-BP

Table 1

Results of isotherms in terms of surface area, total pore volume, micropore volumeof AC materials from variousprecursors

\begin{tabular}{clcccccc}
\hline No & Precursor & Activator & $\begin{array}{c}\mathrm{S}_{\mathrm{BET}} \\
\left(\mathrm{m}^{2} / \mathrm{g}\right)\end{array}$ & $\begin{array}{c}\mathrm{V}_{\text {total }} \\
\left(\mathrm{cm}^{3} / \mathrm{g}\right)\end{array}$ & $\begin{array}{c}\mathrm{V}_{\text {micro }} \\
\left(\mathrm{cm}^{3} / \mathrm{g}\right)\end{array}$ & $\begin{array}{c}\mathrm{D}_{\mathrm{p}} \\
(\mathrm{nm})\end{array}$ & Ref. \\
\hline 1 & Straw & $\mathrm{KOH}$ & 494.92 & 0.494 & 0.110 & 3.991 & This work \\
2 & Limonia acidissima shell & $\mathrm{KOH}$ & 250.73 & 0.149 & 0.052 & 2.388 & This work \\
3 & Avocado shell & $\mathrm{KOH}$ & 218.12 & 0.144 & 0.046 & 2.652 & This work \\
4 & Tea waste & $\mathrm{KOH}$ & 393.01 & 0.252 & 0.158 & 2.568 & This work \\
5 & Banana peel & $\mathrm{KOH}$ & 22.11 & 0.062 & 0.002 & 11.391 & This work \\
6 & Date $($ Phoenix dactylifera L.) stone & $\mathrm{H}_{3} \mathrm{PO}_{4}$ & 1225 & 0.618 & - & - & 44 \\
7 & Peanut shell & $\mathrm{ZnCl}_{2}$ & 1642 & 0.42 & - & - & 45 \\
8 & Coconut shell & $\mathrm{ZnCl}_{2}$ & 11652 & $1.29 \pm$ & $0.768 \pm$ & - & 46 \\
9 & Corncob & $\mathrm{KOH}_{132}$ & 3530 & 0.01 & 0.094 & - & 47 \\
10 & Lignocellulosic biomass & $\mathrm{FeCl}_{3}$ & 780.06 & 0.573 & 0.322 & 0.65 & 47 \\
\hline
\end{tabular}


According to BET analysis, the surface area of the activated carbons is in the following order: straw $\left(494.92 \mathrm{~cm}^{2} / \mathrm{g}\right)>$ tea waste $\left(393.01 \mathrm{~cm}^{2} / \mathrm{g}\right)>$ Limonia acidissima shell $\left(250.73 \mathrm{~cm}^{2} / \mathrm{g}\right)>$ avocado shell $\left(218.12 \mathrm{~cm}^{2} / \mathrm{g}\right)>$ banana peel $\left(22.11 \mathrm{~cm}^{2} / \mathrm{g}\right)$. These results revealed that $\mathrm{KOH}$ activation helps increase the surface area and significantly enhances pore development, allowing to obtain activated charcoal from straw with the largest surface area of $494.92 \mathrm{~cm}^{3} / \mathrm{g}$. Therefore, the activated carbon from straw is expected to be a potential material to remove ciprofloxacin (CIP) from aqueous media.

\section{Effect of contact time and initial concentration}

The influence of initial concentration and contact time on the adsorption performance of the five activated carbons is shown in Figure $4(a, b)$. To assess the removal efficiency of the five adsorbents, the antibiotic concentrations and the adsorbent dosage were fixed at $20 \mathrm{mg} / \mathrm{L}$ and 1 $\mathrm{g} / \mathrm{L}$, respectively. Figure 4 (a) shows that the ACST sample has the highest CIP removal efficiency, reaching $93.34 \%$. While the remaining four materials have adsorption efficiencies below $50 \%$. Specifically, CIP removal efficiency reaches $47.97 \%, 39.49 \%, 31.67 \%$ and $23.43 \%$ for AC-BP, AC-AS, AC-TW and AC-LAS samples, respectively.

Figure 4 (b) illustrates variations in CIP removal over 240 minutes of contact time. For all the AC samples, the CIP removal efficiency seemed to increase rapidly in the first 10 minutes. Specific to the AC-ST sample, the equilibrium was attained after $60 \mathrm{~min}$, and after this point the efficiency ceased to improve and remained stable for the rest of the duration. As for the remaining four AC samples (AC-LAS, AC-AS, AC-TW and AC-BP), increasing contact time from 10 to 180 minutes improved the adsorption efficiency. However, the improvements were modest and varied with the type of the AC sample. Therefore, the experiment can last 60 minutes for AC-ST, and 180 minutes for samples AC-LAS, AC-AS, AC-TW and AC-BP. For the sake of comparison, Table 2 provides results on removal efficiencies attained by various adsorbents.

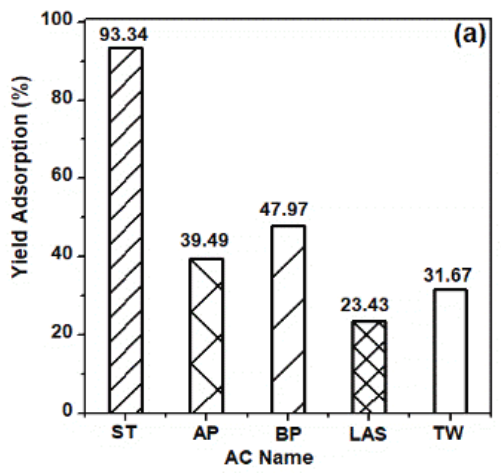

Figure 4: Effect of (a) contact time, (b) initial concentration on removal CIP using AC

Table 2

Surface area and pore volume of AC materials from various precursors

\begin{tabular}{llcc}
\hline No & Adsorbent & \% Removal & Ref. \\
\hline 1 & Straw-based AC & 93.34 & This work \\
2 & Limonia acidissima shell-based AC & 23.43 & This work \\
3 & Avocado shell-based AC & 39.49 & This work \\
4 & Tea waste-based AC & 31.67 & This work \\
5 & Banana peel-based AC & 47.97 & This work \\
6 & Horizontal-flow anaerobic immobilized biomass & 97 & 48 \\
7 & Nano-sized magnetite & $45-80$ & 49 \\
8 & Lignocellulosic biomass by microwave pyrolysis & 96.12 & 50 \\
9 & Low-cost biochar derived from herbal residue & $36-100$ & 51 \\
10 & Duckweed Lemna minor & $>80$ & 52 \\
11 & Freshwater microalga Chlamydomonas mexicana & $13 \pm 1$ & 53 \\
\hline
\end{tabular}



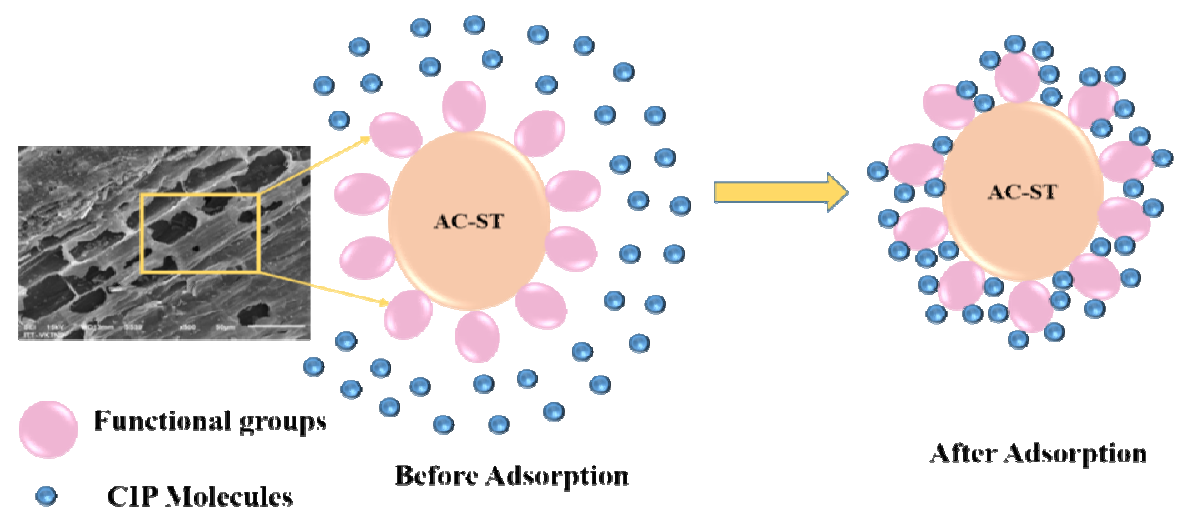

Scheme 1: Proposed adsorption mechanism of CIP antibiotics onto AC-ST

\section{Mechanism for adsorption}

To gain a further insight into the adsorption process onto $\mathrm{AC}$, the corresponding mechanism was proposed in Scheme 1. On the AC surface, a large number of functional groups, such as carboxyl, hydroxyl and ketone groups, are present $^{54}$ and play an important role in improving the removal properties of the adsorbent. These functional groups bond with CIP molecules, thus causing the surface adsorption phenomenon. A possible explanation for the proposed interaction may be the $p-p$ dispersion interaction, the hydrogen bonding formation and the electron donor-acceptor complex mechanism. ${ }^{55}$ However, the exact mechanism that is responsible for the surface adsorption is still unclear and thus requires further investigation.

\section{CONCLUSION}

Five activated carbon samples were successfully synthesized by $\mathrm{KOH}$ activation and their properties were analyzed. All the samples exhibited amorphous carbon structure, were porous materials, with many surface pores. The results showed that the activated carbon produced from straw has the highest surface area (494.92 $\left.\mathrm{m}^{2} / \mathrm{g}\right)$ and the highest pore volume $\left(0.494 \mathrm{~cm}^{3} / \mathrm{g}\right)$ among all the samples produced from agricultural wastes in the present study. More interestingly, the surface consists of many functional groups, contributing to enhanced adsorption capacity. Thus, the results of the adsorption experiments showed that activated carbon from straw reached the highest CIP removal efficiency of $93.34 \%$, compared to the remaining activated carbon samples. Besides, a mechanism was proposed to provide a further insight into the adsorption process onto AC-ST. Therefore, activated carbon from straw has the potential to be used as an effective adsorbent to remove CIP from aqueous media.

ACKNOWLEDGEMENTS: This research is funded by Vietnam National Foundation for Science and Technology Development (NAFOSTED) under the grant number 104.052018.336.

\section{REFERENCES}

1 A. Mamaní, N. Ramírez, C. Deiana and M. Giménez, J. Environ. Chem. Eng., 7, 103148 (2019), https://doi.org/10.1016/j.jece.2019.103148

2 X. Zhang, X. Mao, L. Pi, T. Wu and Y. Hu, J. Environ. Chem. Eng., 7, 103066 (2019), https://doi.org/10.1016/j.jece.2019.103066

3 S. Nirmaladevi and N. Palanisamy, Cellulose Chem. Technol., 53, $1029 \quad$ (2019), https://doi.org/10.35812/CelluloseChemTechnol.2019. 53.101

4 R. Rajbhandari, L. K. Shrestha and R. R. Pradhananga, J. Inst. Eng., 8, 211 (1970), https://doi.org/10.3126/jie.v8i1-2.5113

5 A. T. Folorunsho, U. R. Isotuk and A. I. Job, J. Chem. Env. Biol. Eng., 1, 11 (2016), https://doi.org/10.11648/j.jcebe.20160101.13

6 L. Karimnezhad, M. Haghighi and E. Fatehifar, Front. Environ. Sci. Eng., 8, 34 (2014), https://doi.org/10.1007/s11783-014-0695-4

7 C. L. Zhang, G. L. Qiao, F. Zhao and Y. Wang, J. Mol. Liq., $\quad$ 163, $53 \quad$ (2011), https://doi.org/10.1016/j.molliq.2011.07.005

8 R. Li, Z. Wang, J. Guo, Y. Li, H. Zhang et al., Water Sci. Technol., 77, 1127 (2018), https://doi.org/10.2166/wst.2017.636

9 S. Mopoung, S. Inkum and L. Anuwetch, Carbon Sci. Tech., 3, 24 (2015), http://www.applied-science- 
innovations.com/cst-web-site/CST-HTML-

PAGES/CST-154.html

10 H. T. Ma, V. T. T. Ho, N. B. Pham, L. G. Bach and T. D. Phan, Appl. Mech. Mater., 876, 91 (2018), https://doi.org/10.4028/www.scientific.net/AMM.876. 91

11 A. Kumar and H. M. Jena, Appl. Surf. Sci., 356, 753

https://doi.org/10.1016/j.apsusc.2015.08.074

(2015),

12 J. Kumar, M. Kaur and B. Adiraju, Mater. Today $\begin{array}{llll}\text { Proc., } & 5 & 3334 & \text { (2018), }\end{array}$ https://doi.org/10.1016/j.matpr.2017.11.576

13 M. I. Inyang, B. Gao, Y. Yao, Y. Xue, A. Zimmerman et al., Crit. Rev. Environ. Sci. Technol., 46, 406

(2016)

https://doi.org/10.1080/10643389.2015.1096880

14 S. Norouzi, M. Heidari, V. Alipour, O. Rahmanian, M. Fazlzadeh et al., Bioresour. Technol., 258, 48 (2018), https://doi.org/10.1016/j.biortech.2018.02.106

15 M. J. P. Brito, C. M. Veloso, L. S. Santos, R. C. F. Bonomo and R. da C. I. Fontan, Powder Technol., 339, 334

(2018)

https://doi.org/10.1016/j.powtec.2018.08.017

16 A. M. Aljeboree, A. N. Alshirifi and A. F. Alkaim, Arab. J. Chem., 10, S3381 (2017), https://doi.org/10.1016/j.arabjc.2014.01.020

17 J. M. Dias, M. C. M. Alvim-Ferraz, M. F. Almeida, J. Rivera-Utrilla and M. Sánchez-Polo, J. Environ. Manage., $\quad 85, \quad 833 \quad$ (2007), https://doi.org/10.1016/j.jenvman.2007.07.031

18 M. A. Yahya, Z. Al-Qodah and C. W. Z. Ngah, Renew. Sustain. Energ. Rev., 46, 218 (2015), https://doi.org/10.1016/j.rser.2015.02.051

19 T. Van Tran, Q. T. P. Bui, T. D. Nguyen, V. T. Thanh Ho and L. G. Bach, Water Sci. Technol., 75, 2047 (2017), https://doi.org/10.2166/wst.2017.066

20 A. S. Mestre, A. S. Bexiga, M. Proença, M. Andrade, M. L. Pinto et al., Bioresour. Technol., 102, 8253

(2011),

https://doi.org/10.1016/j.biortech.2011.06.024

${ }_{21}$ A. Wahby, Z. Abdelouahab-Reddam, R. El Mail, M. Stitou, J. Silvestre-Albero et al., Adsorption, 17, 603 (2011), https://doi.org/10.1007/s10450-011-93346

22 S. Gueu, B. Yao, K. Adouby and G. Ado, J. Appl. Sci., 6, 2789 (2006), http://docsdrive.com/pdfs/ansinet/jas/2006/27892793.pdf

23 Z. A. Al-Othman, R. Ali and M. Naushad, Chem. Eng. J., 184, $238 \quad$ (2012), https://doi.org/10.1016/j.cej.2012.01.048

24 L. Gonsalvesh, S. P. Marinov, G. Gryglewicz, R. Carleer and J. Yperman, Fuel Process. Technol., 149, 75 (2016),

https://doi.org/10.1016/j.fuproc.2016.03.024

25 A. S. Mestre, J. Pires, J. M. Nogueira, J. B. Parra, A. P. Carvalho et al., Bioresour. Technol., 100, 1720 (2009), https://doi.org/10.1016/j.biortech.2008.09.039
26 T. Charinpanitkul, P. Limsuwan, C. Chalotorn, N. Sano, T. Yamamoto et al., J. Ind. Eng. Chem., 16, 91 (2010), https://doi.org/10.1016/j.jiec.2010.01.014

27 I. C. Chen, J. K. Hill, R. Ohlemüller, D. B. Roy and C. D. Thomas, Science, 333, 1024 (2012), https://doi.org/10.1126/science.1206432

28 M. Sarker, S. Shin and S. H. Jhung, J. Hazard. Mater., 378, 120761 (2019), https://doi.org/10.1016/j.jhazmat.2019.120761

29 B. N. Bhadra and S. H. Jhung, Micropor. Mesopor. Mater., $\quad 270, \quad 102 \quad$ (2018), https://doi.org/10.1016/j.micromeso.2018.05.005

30 C. R. Verde, Zootaxa, 4205, 480 (2016), http://doi.org/10.11646/zootaxa.4205.5.6

31 Y. Sun, H. Li, G. Li, B. Gao, Q. Yue et al., Bioresour. Technol., 217, 239 (2016), https://doi.org/10.1016/j.biortech.2016.03.047

${ }_{32}$ M. Ashfaq, K. N. Khan, M. Saif, U. Rehman, G. Mustafa et al., Ecotoxicol. Environ. Saf., 136, 31 (2017), https://doi.org/10.1016/j.ecoenv.2016.10.029

33 E.-S. I. El-Shafey, H. Al-Lawati and A. S. AlSumri, J. Environ. Sci., 24, 1579 (2012), https://doi.org/10.1016/S1001-0742(11)60949-2

${ }^{34}$ T. Van Tran, D. T. C. Nguyen, H. T. N. Le, T. T. K. Tu, N. D. Le et al., J. Environ. Chem. Eng., 7, 102881

(2019) https://doi.org/10.1016/j.jece.2019.102881

${ }_{35}$ T. Van Tran, D. T. C. Nguyen, H.-T. T. Nguyen, S. Nanda, D.-V. N. Vo et al., Sci. Pollut. Res., 26, 1 (2019), https://doi.org/10.1007/s11356-019-06011-2

36 M. Sivachidambaram, J. J. Vijaya, L. J. Kennedy, R. Jothiramalingam, H. A. Al-Lohedan et al., New J. Chem., 41, 3939 (2017), https://doi.org/10.1039/C6NJ03867K

37 R. D. Kumar, G. K. Kannan and K. Kadirvelu, J. Bioremediat. Biodegrad., 8, $415 \quad$ (2017), https://doi.org/10.4172/2155-6199.1000415

38 H. Xu, B. Gao, H. Cao, X. Chen, L. Yu et al., J. Nanomater., 2014, 1 (2014), https://doi.org/10.1155/2014/714010

39 S. M. Yakout and G. S. El-deen, Arab. J. Chem., 9, S1155 https://doi.org/10.1016/j.arabjc.2011.12.002

${ }^{40}$ P. Méndez, C. Rivera, C. Pino, R. Mundaca, R. Castillo et al., J. Chil. Chem. Soc., 1, 2805 (2016), http://dx.doi.org/10.4067/S0717-97072016000100012

${ }^{41}$ T. Van Tran, D. T. C. Nguyen, H. T. N. Le, C. D. Duong, L. G. Bach et al., Chemosphere, 227, 455 (2019), https://doi.org/10.1016/j.chemosphere.2019.04.079

${ }^{42}$ D. T. C. Nguyen, H. T. N. Le, T. S. Do, V. T. Pham, D. L. Tran et al., J. Chem., 2019, 1 (2019), https://doi.org/10.1155/2019/5602957

${ }^{43}$ G. Felix, D. Oliveira, R. Carlos, D. Andrade, M. Aparecido et al., Quim. Nov., 40, 284 (2017), https://doi.org/10.21577/0100-4042.20160191

44 M. Danish, R. Hashim, M. N. M. Ibrahim and O. Sulaiman, Biomass Bioenerg., 61, 167 (2014), https://doi.org/10.1016/j.biombioe.2013.12.008 


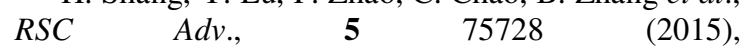
https://doi.org/10.1039/C5RA12406A

46 A. Jain, R. Balasubramanian and M. P. Srinivasan, Chem. Eng. J., 273, $622 \quad$ (2015), https://doi.org/https://doi.org/10.1016/j.cej.2015.03.11 1

47 C. Zhang, Z. Geng, M. Cai, J. Zhang, X. Liu et al., Int. J. Hydrogen Energ., 38, 9243 (2013), https://doi.org/https://doi.org/10.1016/j.ijhydene.2013. 04.163

48 S. K. Theydan and M. J. Ahmed, J. Anal. Appl. Pyrol., $\quad$ 97, 116 (2012), https://doi.org/https://doi.org/10.1016/j.jaap.2012.05.0 08

49 S. Rakshit, D. Sarkar, E. J. Elzinga, P. Punamiya and R. Datta, J. Hazard. Mater., 246-247, 221 (2013), https://doi.org/https://doi.org/10.1016/j.jhazmat.2012.1 2.032
50 M. J. Ahmed and S. K. Theydan, J. Taiwan Inst. Chem. Eng., 45, $219 \quad$ (2014), https://doi.org/10.1016/j.jtice.2013.05.014

51 J. G. Shang, X. R. Kong, L. L. He, W. H. Li and Q. J. H. Liao, Int. J. Environ. Sci. Technol., 13, 2449 (2016), https://doi.org/10.1007/s13762-016-1075-3

52 E. I. Iatrou, A. S. Stasinakis and M. Aloupi, Ecol. Eng., 84, 632 (2015), https://doi.org/10.1016/j.ecoleng.2015.09.071

53 J.-Q. Xiong, M. B. Kurade, J. R. Kim, H.-S. Roh and B.-H. Jeon, J. Hazard. Mater., 323, 212 (2017), https://doi.org/10.1016/j.jhazmat.2016.04.073

54 C. Moreno-Castilla, Carbon, 42, 83 (2004), https://doi.org/10.1016/j.carbon.2003.09.022

55 J. A. Mattson, H. B. Mark, M. D. Malbin, W. J. Weber and J. C. Crittenden, J. Colloid Interface Sci., 31, 116 (1969), https://doi.org/10.1016/00219797(69)90089-7 